\title{
Fábián Zsuzsanna 70 éves
}

Fábián Zsuzsanna a magyarországi italianisztika egyik legismertebb és legelismertebb személyisége, lexikográfusként a „betürendbe rendezett világegyetem”' kutatója. Családi indíttatásból - a köztiszteletben álló tudós, Fábián Pál professzor lelkétől lelkezett - és a sors akaratából korán megnyilvánult a bölcsészettudományok és a nyelvek iránti vonzalma. 1968 és 1973 között az ELTE olasz-német szakán folytatott tanulmányai kitủnő minősítésủ befejezése után előbb rövid ideig az Akadémiai Kiadó Szótárszerkesztőségében dolgozott, ahol - a Kosztolányi Dezső Szótárat lapozgatok címü írásában leírtakhoz hasonlóan - gyorsan megtapasztalta, hogy a szótárnál nincs „gazdagabb, élőbb, lelkesebb valami”, mert benne van a múltunk, a jelenünk és a jövendőnk, benne van az életünk, a halálunk, egyszóval benne van a sorsunk. Fokozatosan tudatosult benne, hogy a szótár a hétköznapi emberek számára is szimbolikus értékü, fontos kiadvány, igazolva ezzel Constantin-François Volnay (1757-1820) francia filozófus, orientalista, akadémikus máig igaz mondását, amely Pierre-Claude-Victor Boiste 1800-ban Párizsban kiadott Dictionnaire universel de la langue française címü híres szótárának címlapján olvasható: „Egy nemzet első számú könyve nyelvének szótára.” A szótárak „lapozgatása”, tanulmányozása és szerkesztése során elsajátította azt a hatalmas lexikográfiai és metalexikográfiai tudást, amelyet sajnos a magyarországi nyelvésztársadalom egy része - némileg szembemenve a nemzetközi irányadó áramlatokkal, talán a kellő ismeretek vagy a társadalmilag azonnal hasznosuló eredmény, sikerélmény megtapasztalásának hiányából fakadóan - a mai napig nem értékel megfelelően.

A szavak, a szólások, a nevek és a szótárak szeretete, vonzása elkísérte több évtizedes oktatói és kutatói pályáján, ami érintette az olasz leíró nyelvészet több területét, a lexikológiát, a lexikográfiát, a vonzatkutatást, a frazeológiát, a névtant, a szociolingvisztikát, valamint az olasz-magyar kapcsolattörténetet. 1973 és 1988 között előbb a JATE (ma SZTE) Olasz Tanszékén, majd azóta az ELTE Olasz Tanszékén diákok hosszú sorát vezette be - a tanársegédi fokozattól az egyetemi tanári fokozatig jutva - a nyelvészet, azon belül is elsősorban a lexikológia, a frazeológia, az onomasztika és a lexikográfia rejtelmeibe. Lelkiismeretes oktatói, oktatásszervezési munkája mellett több szótárt - útiszótárt, vonzatszótárt, szólásszótárt stb. - írt vagy szerkesztett, és jól ismertek e gyakorlati tapasztalaton alapuló elméleti, metalexikográfiai tanulmányai is. Az utóbbi években ő a magyar felelőse a firenzei Crusca-Akadémia által koordinált, nagyszabású projektnek (Osservatorio degli Italianismi nel Mondo, OIM), amelynek célja az olaszból nyolc európai nyelvbe átkerült ,italianizmusok” elektronikus adatbázisban való bemutatása. Az anyanyelvével és az idegen nyelvekkel való elmélyült, igényes kapcsolat számára egyszerre nagy odaadással üzött kenyéradó foglalkozás és felüdülést hozó varázslatos időtöltés. Mert Kosztolányinak a Nyelv és lélek címü tanulmánykötetében megfogalmazottakkal együtt vallja ö is, hogy „a nyelv varázsa $[\ldots]$ éppen az, hogy telis-tele van emberi tartalommal, letủnt nemzedékek életével, okos és ostoba emberek szellemével, akik az indulat hevében nyütték és

${ }^{1}$ Anatole France határozta meg így a szótárt La Vie littéraire című, 1921-ben megjelent művében.

DOI: https://doi.org/10.18349/MagyarNyelv.2021.2.243 
rontották szavait, s úgy hagyták ránk, az érzés megindító szeszélyével együtt. [...] Minden szó ereklye. [...] Családi emlékek évezredes kincstára az élő nyelv. Azért tudunk rajta beszélni, mert hasonlít hozzánk: éppoly eleven és gyarló, mint mi. Édes hibái többet érnek a tökélynél. Jellemezhetjük vele magunkat, kik szintén hibákkal vagyunk teljesek. Szólásai körülhatároltak, de rugalmasak is, annyira tágíthatók és szűkíthetők, hogy lelkünk egész gazdagsága beléjük fér."

Fábián Zsuzsanna lelke különösen gazdag, hisz abban nem egy, hanem három nyelv szavai, szólásai, nevei is kölcsönös vonzalomban férnek meg egymással. E vonzalmát mindennél jobban mutatja az elmúlt évtizedekben készült több mint 226 tudományos publikációja és 635 hivatkozása, itthon és külföldön tartott több tucat előadása, 7 vendégtanári meghívása (Turku, Róma, Firenze, Padova, Udine), társasági tagságai (Magyar Nyelvtudományi Társaság, Modern Filológiai Társaság, Associazione Internazionale di Studi di Linguistica e di Letteratura Italiana, Società di Linguistica Italiana, MTA Köztestület, MTA I. osztálya Nyelvtudományi Bizottsága Szótári Munkabizottsága), szerkesztőbizottsági tagsága (Rivista Italiana di Onomastica, Nuova Corvina, Névtani Értesítő). Munkásságát több kitüntetéssel ismerték el: Kiváló munkáért (1985), Széchenyi Professzori Ösztöndíj (2000-2003), „ELTE Pro Universitate Emlékérem” arany fokozat (2010), Magyar Érdemrend tisztikeresztje polgári tagozata kitüntetés (2020).

A fenti gondolatok vezérfonala a vonzás, vonzódás, vonzalom fogalmak köré szövődött. A lexikológián, a lexikográfián, a frazeológián túl ünnepeltünk vonzódási köre az utóbbi időben egyre inkább a névtan irányába szélesedett ki. A nevek világának kutatása izgalmas és vonzó nemzetközi kutatási távlatokat nyitott számára. A nyelvtudomány egyik legantropomorfabb területén folytatott igen aktív kutatásai során tudatosan tartja szem elött Goethe örökbecsű sorait:

Az embereknek nevet adtok, És a nevekkel nagyra vagytok, Pedig a lélek zugain

Valami mindig anonim.
Ihr sucht die Menschen zu benennen Und glaubt am Namen sie zu kennen. Wer tiefe sieht, gesteht sich frei, Es ist was Anonymes dabei.

Köszöntésem végén fontosnak tartom elmondani még, hogy Fábián Zsuzsannához ötven éves ismeretség, szoros szakmai együttműködés és - ami mindezeknél fontosabb őszinte barátság füz, akinek müveltsége, széles körü tájékozottsága és nyitottsága mindig lehetővé teszi, hogy a nyelvészeti kérdéseken túl az élet megannyi kérdéséről is mély eszmecseréket lehessen folytatni. Amikor megköszönöm neki több évtizedes kollegialitását, segítőkészségét és barátságát, 70. születésnapja alkalmából egyben őszinte szívvel kívánom, hogy mindannyiunk örömére és megelégedésére még nagyon sokáig éljen és alkosson erőben, egészségben a szótárak, szólások, nevek és az olasz kultúra vonzásában. PER MOLTI ANNI ZSUZSA! 